\section{Den landflygtige høvding. Om Georg Brandes' ophold i Berlin 1877-1883}

\author{
af forskningsbibliotekar, cand.phil. Leon \\ Jaurnow, Roskilde Universitetsbibliotek.
}

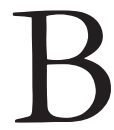

elysningen var dæmpet, og glassene godt fyldte, da en lille kreds af gode venner den 5 . oktober 1877 satte hinanden stævne omkring et festdækket middagsbord i København. Georg Brandes var æresgæst, sad til højbords og blev fejret efter alle kunstens regler. Og det til trods for, at der overhovedet ikke var noget at fejre.

Brandes havde nemlig kort forinden holdt sin foreløbig sidste forelæsning på dansk grund. Han var nu fast besluttet på at forlade landet i vrede og trods, da det stod klart, at man ikke ville indstille ham til det professorat $i$ xstetik, som var blevet ledigt på Københavns Universitet efter professor Carsten Hauchs død. Et professorat, Brandes så sig selvskrevet til og lige siden sin indledningsforelæsning over Hovedstromninger $i$ det 19de Aarhundredes Litteratur i 1871 havde arbejdet for og stræbt mod.

Men nu var det hele tilsyneladende faldet til jorden. Brandes' modstandere på Danmarks akademiske kampplads havde trukket det længste strå og indtil videre afskåret ham fra den eftertragtede stilling på universitetet. De mente blandt andet, at han med sine "Hovedstrømninger" havde ytret sig alt for kritisk over for det etablerede samfunds familieopfattelse og dannelsesideal, og fremførte $i$ en lind strøm deres utilfredshed på avisernes debatsider. Så man kan roligt sige, at Brandes hang en anelse med skuffen, dér på sin æresplads i den dæmpede belysning, mens vennerne flittigt slog på glassene og med afskedssalutter og opmuntrende taler forsøgte at sige ham pænt farvel:

"Du er overalt Ild" lød det højstemt fra vennen og kunsthistorikeren, Julius Lange, $i$ en hyldest af Brandes og hans glødende lidenskab og engagement. ${ }^{1}$ Og digteren Holger Drachmann havde til lejligheden forfattet et helt afskedskvad, der blandt andet indeholdt følgende passus:

"Hvad hjælper det, hans Mund er fyldt med Vin

og Honning, som det gamle Kanaans

Floder?

Han taler for et Folk, som sætter Grin i Punsch højt over alle lyse Ho'der. Hvad hjælper al Dikteren hos hans Moder, naar Folket strømmer helst til Gøglerboder

og køber for en Slik sin Aandsbespisning?

Hos Brandes vanker Tugt og TankeRisning, og er hans Ris end svøbte i Silke tidt: Man mærker dog på Hylet, det har bidt!"2

Således opløftet af alle gode ord, kunne Brandes sidst på aftenen løfte sit glas og byde selskabet et farvel og tak. Næste morgen forlod han Danmark og vendte skosnuder, tankerisning og hovedstrømninger mod Berlin. Det 


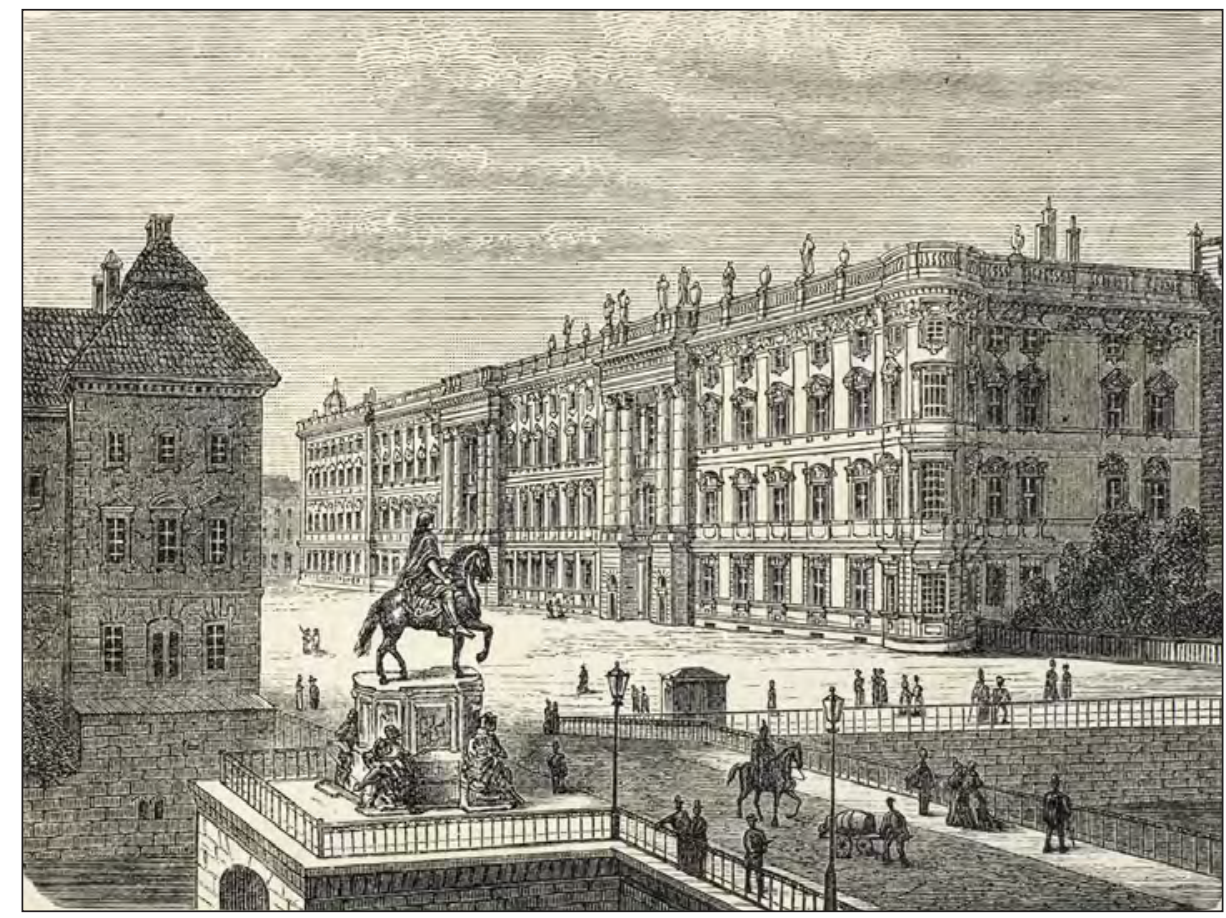

Slottet $i$ Berlin blev opfort i flere omgange, fra midten af 1400-tallet. Det fungerede som residens for markgreven og kurfyrsten af Brandenburg, senere for kongen af Preußen og den tyske kejser. Det lå på Spreeinsel $i$ bydelen Mitte. Efter Novemberrevolutionen 1918 blev slottet bl.a. museum. Det blev svart beskadiget under anden verdenskrig og blev revet ned $i$ 1950. På stedet opfortes $i$ stedet for Palast der Republik, nedrevet 2006-2008. Fra Berlin som tysk Rigshovedstad, 1885 (Det Kongelige Bibliotek).

blev indledningen til godt fem års landflygtighed med mismod og pengenød, men også arbejdsglæde og anseelse, i den tyske hovedstad.

\section{In den Zelten 16}

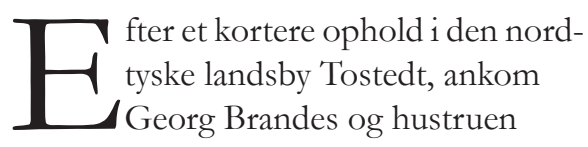

Gerda den 12. oktober 1877 til deres nye lejlighed på adressen In den Zelten 16, tre etager op, i det nordvestlige Berlin. Brandes var glad over at være nået frem, men også tydeligt berørt over udsigten til nu at skulle finde fodfæste i frem- mede omgivelser. Det fremgår klart af følgende erindringsglimt, som Brandes 30 år senere nedfældede i selvbiografien Levned:

"Jeg havde den underligste Følelse, da jeg satte mig ned i mit fremtidige Sovekammer paa en Kasse som Stol ved en anden Kasse som Bord, med en ussel Stump Lys. Jeg var lige kommen hjem efter at have vandret ensom omkring i Gaderne, hvor Jernskodderne var rullede ned for Butikerne, og Folk i den fugtige Oktobertaage, saa fremmede og ligegyldige ud. Jeg sad nu og spurgte mig selv: Kan jeg erhverve mig en Plads 
i dette Land? Hvorfra skal jeg faa de nødvendige Penge? - De første uundgaaelige Udgifter forekom mig kolossale. Og Alt, hvad jeg besad, var et Laan paa 3000 Kroner, som min Broder ædelmodigt havde forstrakt mig med. Aandeligt følte jeg mig fuldstændig alene (...).”’3

Brandes stod ved år nul i sit nye liv og måtte på mange måder begynde helt forfra. Lejligheden i Berlin skulle indrettes, og møbler bestilles. De første dage nærmest løb han fra Herodes til Pilatus for at afhente de kufferter, kasser og pakkenilleker, der var afsendt fra Danmark. Det var sin sag at gå fra at være professorkandidat og bannerfører for en hel kulturkamp i København til pludselig at se sig selv som rodløs eksildansker og fortravlet bybud i Berlin.

Men Brandes bød de indledende genvordigheder trods og $\mathrm{i}$ takt med, at kufferterne blev pakket ud, og der ved hustruen Gerdas overblik kom styr på lejligheden, fik han så småt overskud til at se lidt lysere på sine nye omgivelser. "Værelserne ere meget gode. Udsigten ligefrem deilig især i et saadant Sollys som idag", som han skrev hjem til sine forældre i København, den 14. oktober $1877 .{ }^{4} \mathrm{Nu}$ var Berlin ikke blot lig med nedrullede jernskodder og oktobertåge for Brandes, men også en indbydende by med smukke bygningsværker og grønne parker, som det videre fremgår af hans brev til forældrene:

"Til alle Sider for mine

Øine som et grønt Hav Kronerne af Thiergartens smukke Træer. Tilvenstre skinner Seirssøjlens gyldne Victoria i sin hele skjærende Glands mod en lyseblaa solklar Himmel. I nogen Afstand

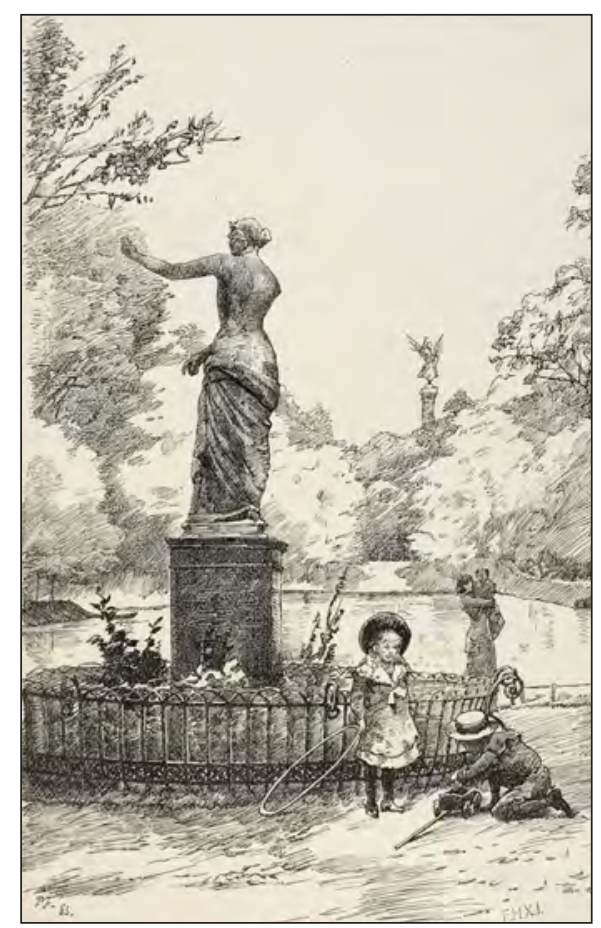

Tiergarten er en 210 bektar stor park $i$ bydelen

Tiergarten midt i Berlin. Landskabsparken blev skabt af Peter Joseph Lenné i 1830. Her guldfiskeparken. Fra Berlin som tysk Rigshovedstad, 1885 (Det Kongelige Bibliotek).

overfor mig ligger Krolls Theater mellem Træerne og til venstre begrændses Horizonten af nogle Kirkekupler. Jeg gik mig før min første Tur i Thiergarten; tænk dig 6 Frederiksberghaver og et Par Søndermarker gjennemskaarne af Alleer for Kjørende og Ridende i Efteraarets hele Farvepragt og i fuldstændig Sommervarme saa har du Indtrykket den nu gjør. Det er en meget heldig Spadsertur at have." 5

Under trækronerne i Tiergartens rolige omgivelser kunne Brandes samle sine tanker og gøre status over sin situation. Hjemme i Danmark rasede 


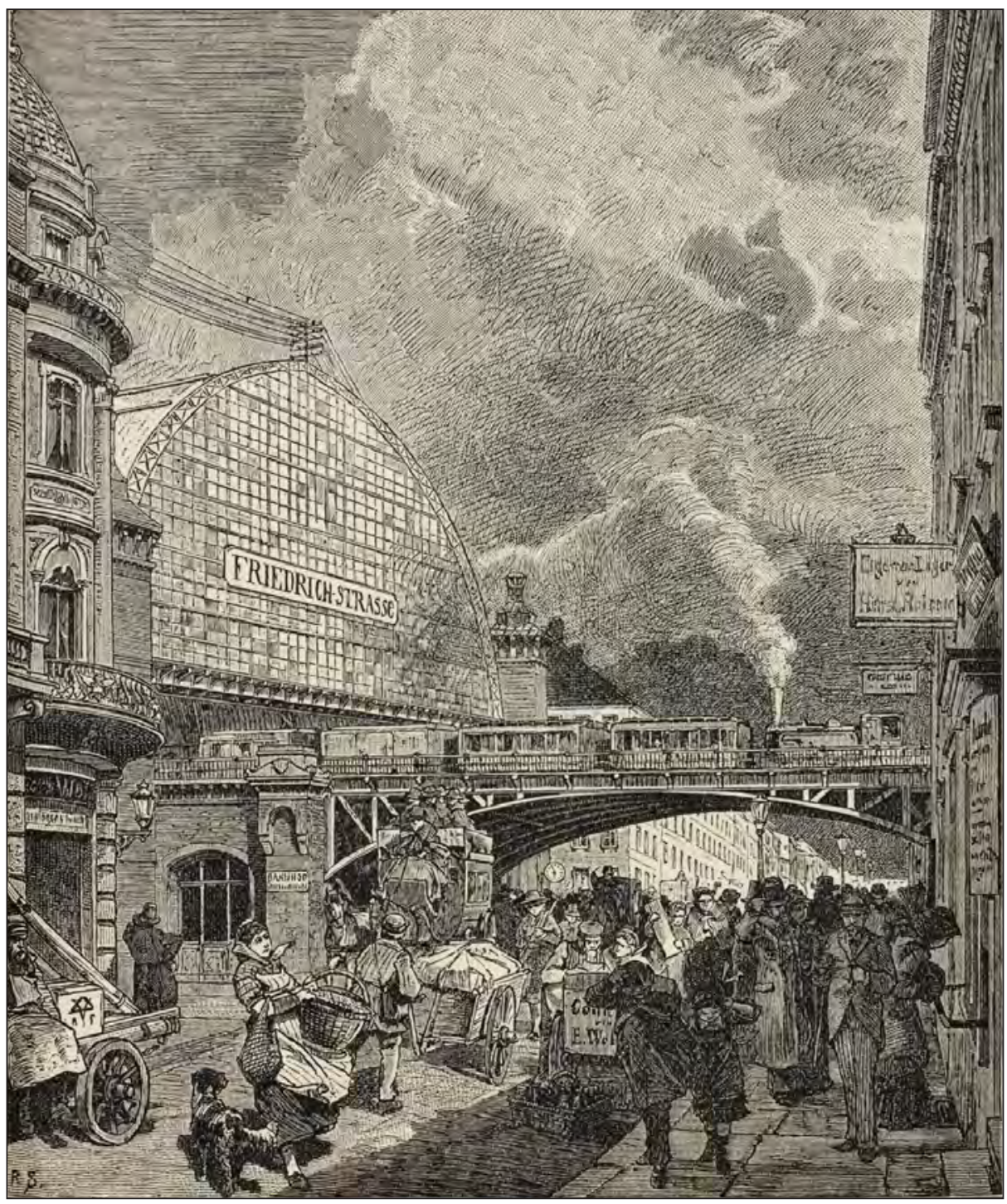

Friedrichstrasse Station fra 1878 blev fra begyndelsen et vigtigt berlinsk. trafikalt knudepunk.t. Georg Brandes var meget imponeret; over hojden, bredden, hyset, den hensigtsmassige indretning. Fra Berlin som tysk Rigshovedstad, 1885 (Det Kongelige Bibliotek).

sagen om hans professorkandidatur med uformindsket styrke. Aviserne bugnede fortsat af kritiske indlæg fra Brandes' modstandere - "Skældeartikler af lavtliggende Art", som Brandes kaldte dem ${ }^{6}$
- men også af indlæg fra hans mange tilhængere, der talte hans sag og forsvarede ham med næb og klør.

Brandes selv deltog ikke i pennefejden; det overlod han til sine tro 
væbnere i København. Han havde så rigeligt at gøre med at finde sig selv og få fast grund under fødderne i Berlin. 'Jeg har desuden havt et Slør af Mismod over Hovedet siden jeg reiste hjemmefra", som han betroede broderen Edvard i et brev dateret 27 . november 1877. "Ikke at jeg ønsker mig tilbage: det mindst; men jeg er endnu ei kommet i nogen stadig Arbeidsskure og føler mig derved saa underligt uden Felt." 7

At være forsmået professorkandidat og dagligt se sig kritiseret i landets aviser, det var én ting, som selvfølgelig satte sig spor i Brandes' selvfølelse og forfængelighed. Men at føle sig stækket i sit arbejde og traske rundt i lediggang, det var noget helt andet og langt mere end den bortrejste bannerfører kunne bære. Der skulle ord på papiret og bøger på bordet, hvis Brandes på nogen måde skulle finde sig tilrette $i$ Berlin.

\section{Arbejdsglæde og pengesorger}

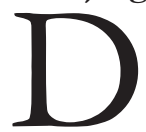
en følgende tid stod derfor $\mathrm{i}$ indlevelsens og arbejdets tegn. Brandes begyndte at knytte kontakter til forfattere, politikere og videnskabsmænd og troppede velvilligt $\mathrm{op}$, når der blev inviteret til middage $\mathrm{og}$ sammenkomster i Berlin og omegn. I brevene hjem til familie og venner i København berettede Brandes om varme retter, sjældne vine og endeløse rækker af betydningsfulde personager, der nu var blevet en del af opholdet i Berlin.

Og fra salonernes bonede gulve gik turen ud i byens rum, hvor Brandes tog pulsen på kulturlivet. Alene og arm i arm med hustruen Gerda gik han $\mathrm{i}$ teatret og på kunstudstillinger. Han så tyske opførelser af Shakespeares skuespil, hørte italiensk opera og var med alle sine sanser tilstede i den fascinerende og kosmopolitiske hovedstad. Men byture og selskabelighed gjorde det ikke alene, der skulle også produceres. Brandes begyndte at skrive situationsrapporter og analyser af samfundsforhold og kulturelle tilstande i samtidens Berlin; først og fremmest til norske og svenske aviser - Dagbladet, Göteborgs Handels- och Sjöfarts-Tidning, Stockholms Morgenblad, Aftonbladet med flere - men også tyske, østrigske og danske aviser nød med tiden godt af hans beskrivelser af byens åndsliv og fysiognomi. Brandes samlede senere et udvalg af sine mange artikler i bogen Berlin som tysk Rigshovedstad, der udkom i 1885 .

Og Brandes kastede sig over mere arbejde. I et brev til moderen, dateret 11. november 1877, skrev han blandt andet, at "Bibliotheket her er udm. Forsynet med svensk Litteratur og jeg læser nu blot Svensk i det Haab at faa Noget ud af det." ${ }^{\text {" }}$ Det fik han. I maj 1878 kunne han således efter nogen tids intensivt arbejde udgive bogen

Esaias Tegnér, der var et nærstudie af den svenske forfatters liv og værk.

En anden person, der optog Brandes i Berlin, var den engelske forfatter og statsmand Benjamin Disraeli. Lige siden arbejdet med Naturalismen $i$ England, der i 1875 udkom som fjerde bind i serien om Hovedstromninger $i$ det 19 de Aarbundredes Litteratur, havde Brandes interesseret sig for Disraelis virke. I Berlin besluttede han sig for at forfølge 


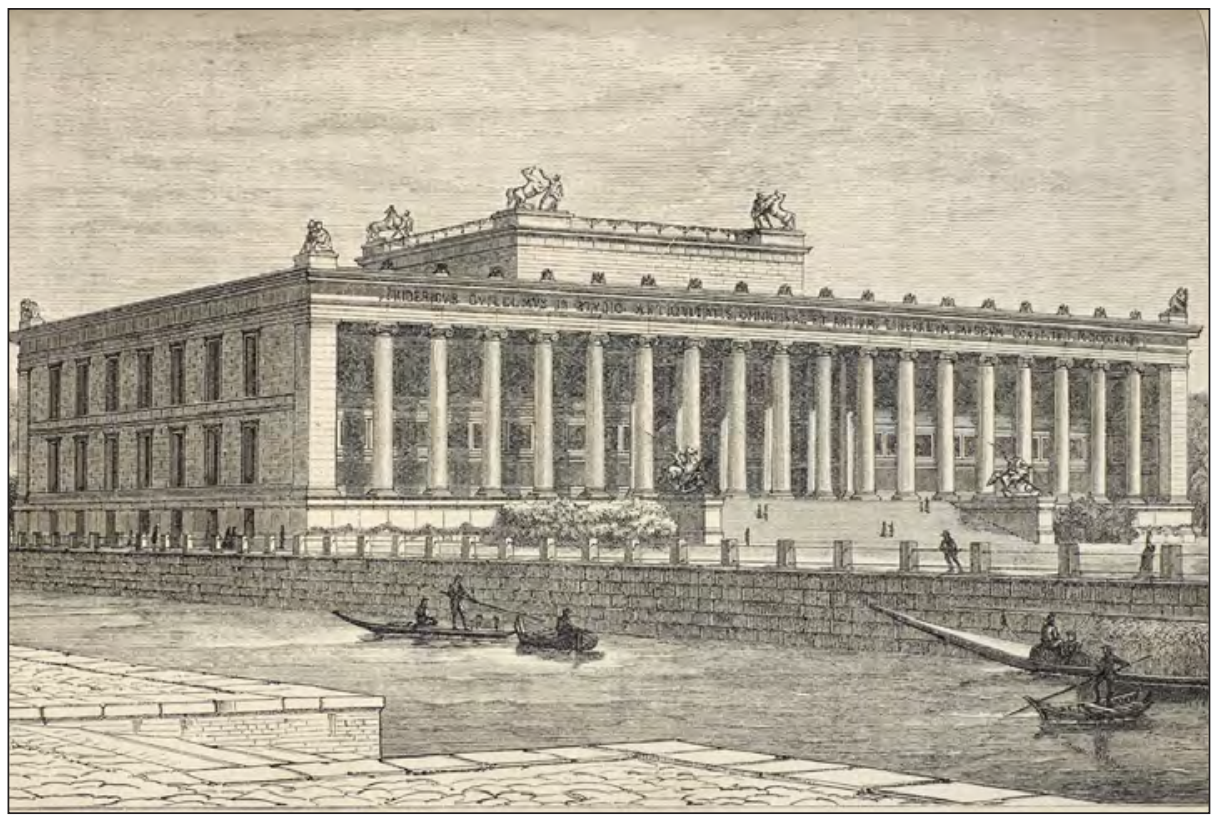

Altes Museum er det celdste museum på Museumsinsel i Berlin. Det blev opfort 1825-1828 af Karl Friedrich

Schinkel $i$ klassisk stil. Det rummer blandt andet antiksamlingen. Fra Berlin som tysk Rigshovedstad, 1885 (Det Kongelige Bibliotek).

denne interesse og skrive hans biografi. Et arbejde, Brandes gik til med stor entusiasme og energi, som det fremgår af hans brev til filologen og politikeren Victor Pingel, dateret 7. december 1878:

"Igaar aftes Kl. 9 skrev jeg den sidste Linie af min Bog. Saavidt kom jeg efter 14 Timers Arbeide daglig i de sidste to-tre Uger og efter den sidste Nat at have anvendt den Methode vexelvis at lægge mig og staae op og skrive et Par Timer. Det vil blive en Bog paa 20 Ark, en psychologisk Analyse, som jeg - hvis jeg maa prale - tør sige, at ikke Enhver gjør mig efter."’

Brandes var således tydeligt tilfreds med resultatet af sine anstrengelser og sendte det færdige manuskript til Gyldendalske Boghandels Forlag i Kø- benhavn. Den 12. december 1878 trådte han ind på den litterære scene som politisk portrættør med bogen Benjamin Disraeli, Jarl af Beaconsfield.

Bogudgivelserne og arbejdsrelationerne til diverse dagblade gjorde ikke bare godt i Brandes' mentale husholdning og gav ham en følelse af selvværd i eksiltilværelsen, de gav med deres tilhørende honorarudbetalinger også et helt nødvendigt tilskud til husholdningskassen. De 3000 kroner, som Brandes ved afrejsen havde lånt af broderen Edvard, rakte ikke langt, når først huslejen og kosten var betalt. Og da ægteparret Georg og Gerda under opholdet i Berlin tilmed ventede familieforøgelse - datteren Edith blev født den 17. januar 1879 og datteren Astrid den 28. marts 1880 
- så måtte der indtjening til for at skabe balance i regnskabet.

Det var ikke altid nogen nem opgave at få indtægterne til at stå mål med udgifterne - faktisk langt fra. Det var dyrt at bo i Berlin, og Brandes klagede da også jævnligt over pengesorger i sine breve hjem til familie og venner.

Indimellem stod det så sløjt til med økonomien i Berlin, at pengenøden lå som en tung dyne over hverdagen og direkte lammede Brandes i hans udfoldelsesmuligheder. Det huskede han blandt andet således i sin selvbiografi: "En Majdag havde jeg kun fire Mark tilbage, en Junidag kun en Mark. En Eftermiddag maatte jeg negte mig hjemme for en ung Gesandtskabssekretær, fordi det var mig umuligt at byde ham en Kop The, og det var Thetid. I Sommeren 1878 maatte jeg sende Afbud til et Selskab, hvor jeg ventedes, fordi jeg ikke havde Penge til en Vogn." 10 Det var da også snarere reglen end undtagelsen, at Brandes måtte gå den tunge gang og låne penge af familien i København for at få tilværelsen In den Zelten 16 til at hænge sammen.

\section{Jagten på anseelse}

9 Når truget er tomt, bides hestene", lyder et gammelt ordsprog, og der er da heller ingen tvivl om, at det daglige lavvande i økonomien i perioder kilede sig forstyrrende ned i den ægteskabelige harmoni mellem Georg og Gerda. Så muligvis har det også været for at slippe lidt væk hjemmefra, men helt sikkert var det for at skaffe klingende mønt til brødet, at Brandes fra sin berlinske platform begyndte at drage ud for at holde forelæsninger.

Turen gik blandt andet rundt i Tyskland - Hamburg og Bremen men Brandes var også på forelæsningsturneer i Norge, Polen og Danmark. Fra talerstole på universiteter og akademier forelæste han over fransk litteratur og romantik. Et emne, Brandes havde taget op og fordybet sig i som led i sine forberedelser til bogen Den romantiske Skole i Frankrig, der udkom i december 1882 som femte bind i serien om Hovedstromninger $i$ det 19 de Aarbundredes Litteratur. Men Brandes var også mand for at levere forelæsninger om forfatterne Bjørnstjerne Bjørnson, Henrik Ibsen og Schack Staffeldt.

I modsætning til honorarudbetalingerne i forbindelse med Brandes' bogudgivelser og artikler, der godt kunne trække ud, så var der anderledes hurtig og kontant afregning ved forelæsningerne. Og det har været en lise i alle de pekuniære bekymringer.

Den udadvendte forelæsningsvirksomhed sikrede dog ikke blot brød på bordet, den var også med til at styrke Brandes' anseelse i udlandet. En anseelse, han arbejdede meget målrettet mod under sit ophold i Berlin. Som høvding for en kulturkamp i Danmark - ja, i hele Norden - nød Brandes stor respekt blandt sine venner og kampfæller på hjemmefronten. Samme respekt og anseelse skulle på mange måder erhverves på ny i tilværelsen som landflygtig høvding.

Brandes' breve og erindringer fra Berlin-tiden vidner da også om stor optagethed af sagen. I et brev til moderen, dateret 26. december 1877, luftede 


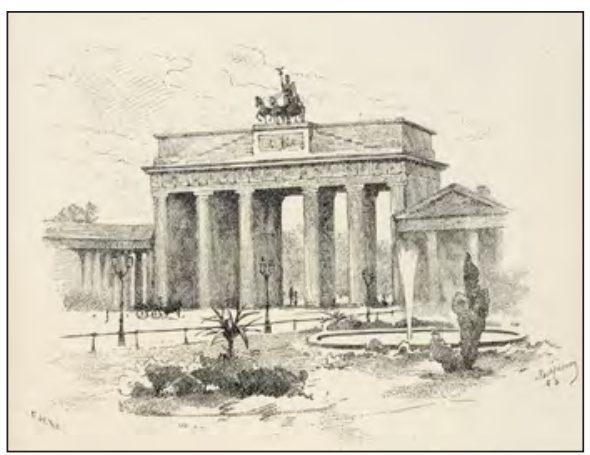

Brandenburger Tor på Pariser Platz blev opfort 17881791 og betragtes som byens vigtigste vartegn. Porten er $26 \mathrm{~m}$ hoj, 65,5 m bred og $11 \mathrm{~m}$ dyb. Fra Berlin som tysk Rigshovedstad, 1885 (Det Kongelige Bibliotek).

han således følgende idé: "Jeg maa fortælle dig - men snak ei om det, da det muligt intet bliver til - at jeg har faaet den Idee at ville optræde offentl. som Thaler her i Berlin (...) det vilde giøre mig meget bekjendt og vilde altid vække Interesse at en Fremmed talte."11

Brandes var ligeledes meget opsat på at få sine nyskrevne bøger om Tegnér og Disraeli/Beaconsfield oversat og udgivet i Tyskland så hurtigt som muligt, så der kunne falde lidt håndører af og blive skabt opmærksomhed omkring hans arbejde og person. $\mathrm{Og}$ det gav bonus, som det fremgår af hans tilbageblik i Levned: "Fra Begyndelsen af Aaret 1879 kunde jeg spore en stærk Stigen af min Anseelse i Tyskland og Østrig. Neppe var min Bog om Lord Beaconsfield udkommen, før det østrigske Verdensblad Neue freie Presse tilbød mig Overtagelsen af Bladets hele Udenrigspolitik. Jeg fik dernæst et Tilbud fra Firmaet Rütten \& Loening i Frankfurt am Main om Udgivelsen af et Bind Essays og et Tilbud fra Ludwig
Geiger om Medarbejden paa GoetheAarbogen." 12

Med knofedt og ved hårdt arbejde fik Brandes tilkæmpet sig en position og slået sit navn fast i Europa. Måske ikke i det omfang, han havde håbet på og drømt om, da han vendte Danmark ryggen og drog ud for at formidle hovedstrømninger i det europæiske åndsliv. Men nok til at han i sit berlinske eksil trods alt følte sig værdsat og påskønnet.

Han navn vat sågar oppe at vende, da man ved universitetet i Wien, december 1878, var på udkig efter en ny professor i tysk litteratur. En stilling Brandes var meget interesseret $i$ af to grunde: "1) Fordi det endelig engang er en sikker Indtægt. 2) Fordi det dog er en ikke ringe Ære for mig som Fremmed at blive kaldt til Professor i en tydsk Hovedstad af den Rang. Nu faae vi see om det ei paany Alt bliver til Røg", som han skrev til moderen, den 18. december $1878 .{ }^{13}$

Røg blev det. Brandes indgav på opfordring sin ansøgning til det østrigske undervisningsministerium og ventede. $\mathrm{Og}$ ventede. Han havde således masser af tid til at tænke søde tanker om endelig at kunne skrive professor på sit visitkort. Det ville for alvor lukke munden på kritikerne og stive hans selvfølelse af efter det svidende nederlag og tumulten omkring professoratet $\mathrm{i}$ København.

Men efterhånden som tiden gik uden svar, svandt Brandes' håb: "(...) jeg skjuler ei for mig selv at mine Udsigter nu ere meget ringe. Der maa jo have vist sig Hindringer ellers varede 
de ei saa længe", som han tre måneder senere fastslog over for moderen. ${ }^{14} \mathrm{Hin}$ dringen mellem Brandes og en ansættelse som professor i Wien skulle vise sig at ligge i sproget. Når alt kom til alt, så mente man fra det østrigske ministeriums side alligevel ikke, at Brandes besad de nødvendige tyskkundskaber. Så endnu engang måtte han lide den tort at træde an i rollen som forsmået professorkandidat.

\section{Auf Wiedersehen Berlin}

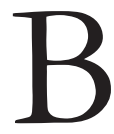

randes bed skuffelsen i sig og fortsatte sin gerning. Han forelæste, skrev breve, artikler og bøger. Han kortlagde litterære tendenser, indkredsede tilstande i tidsånden og bestræbte sig sideløbende på at gøre fyldest i rollen som forsørger og familiefar $i$ lejligheden tre etager op i det nordvestlige Berlin.

Der er ingen tvivl om, at det har været hårdt for Brandes konstant at være forpligtet til at skrive for brødet og jage anseelse og ansættelse. Som årene gik følte han sig da også godt brugt og slidt i betrækket. Stress-symptomer som uro, søvnløshed og mismod tog over, og tanken om at smide håndklædet $\mathrm{i}$ ringen og vende næsen hjem var begyndt at melde sig: "Min 'Modløshed' hænger, troer jeg, sammen med min alt for store Ensomhed og Isolerthed og herom har jeg, siden jeg kom, villet skrive til dig confidentielt", som han betroede broderen Edvard, den 15. november 1881. "Jeg mener, det er galt, at jeg bliver her; jeg fortryder ei i mindste Maade at være kommen hertil eller disse fire Aar, men jeg mener, det er galt for mig at blive

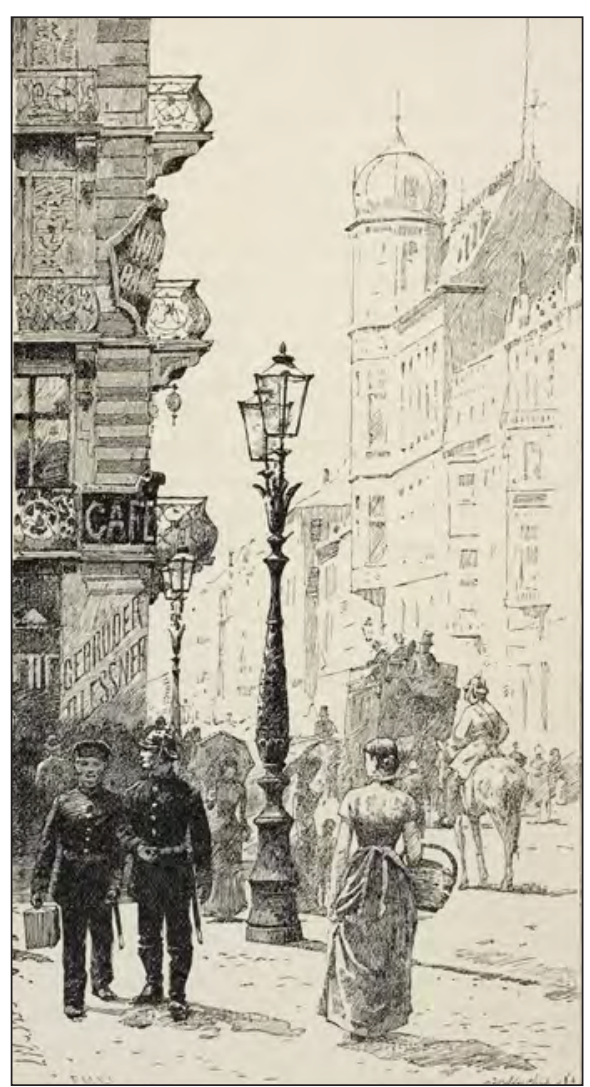

En gade i Berlin. Fra Berlin som tysk Rigshovedstad, 1885 (Det Kongelige Bibliotek).

længer." ${ }^{15}$

Modløsheden og hjemveen bed sig fast. Men hvordan opgive de store planer om at blive åndshøvding $\mathrm{i}$ Berlin uden at miste respekt og anseelse? Hvordan vende hjem til København uden at landflygtigheden blev opfattet som en ren fiasko? De spørgsmål lå længe som en ulmende hovedpine hos Brandes. I et brev til Edvard, skrevet februar 1882, opridsede han situationen således:

"Jeg vil stedse hjem, men jeg vil ei vende hjem paa et urigtigt Tids- 


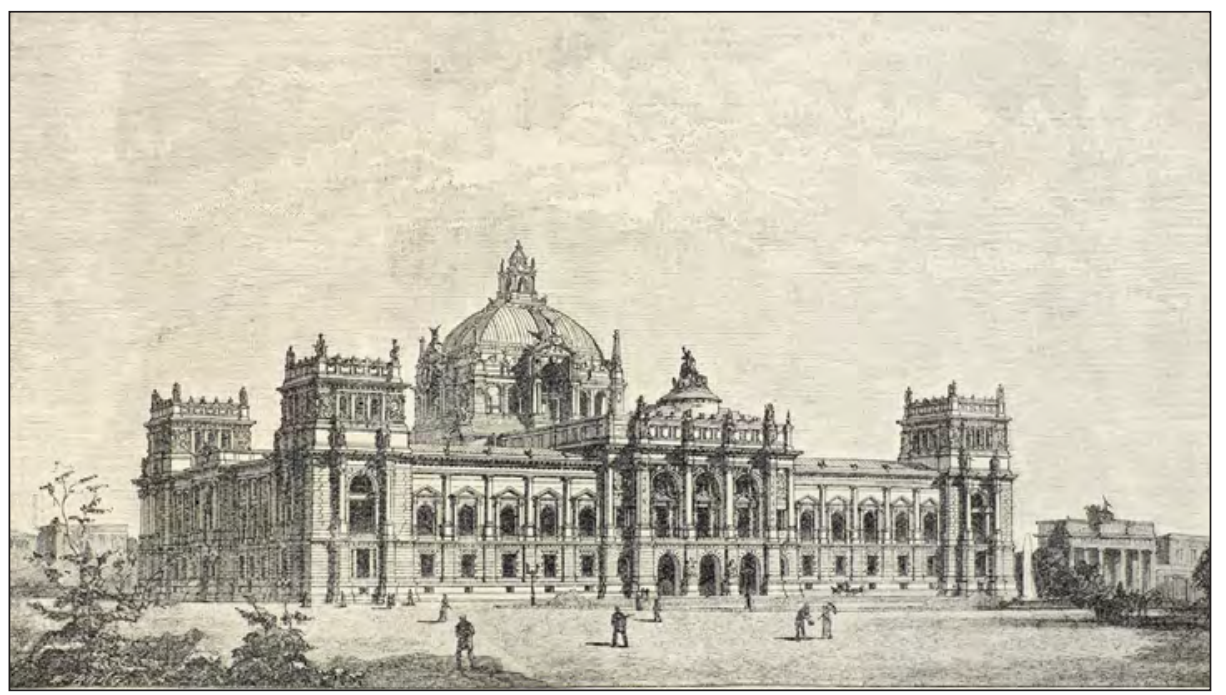

Den projekterede Rigsdagsbygning. Den blev opfort 1884-1894 i nyrenassancestil. Indtil 1918 var den modestedet for det tyske kejserriges rigsdag - og efterfolgende for Weimarrepublikekens. Rigsdagsbranden 1933 og skaderne $i$ anden verdenskrig kravede omfattende istandsattelser, senest 1991-1999. Fra Berlin som tysk Rigshovedstad, 1885 (Det Kongelige Bibliotek).

punkt, ei gjerne komme ukaldet. Jeg frygter for man skal troe, det ei gaaer mig godt i Tydskland, og at jeg dog ei kan undvære Danmark, saa at jeg altsaa med Et (admodum Gambetta) taber hvad Prestige jeg i Løbet af mange Aar har samlet. Saa pekuniært: At flytte tilbage er enormt dyrt for mig. Sælger jeg mine Møbler ved Auction, mister jeg dem for en Spotpris. Og tager jeg dem med, vil, som jeg efter Vægten kan udregne i Forhold til hvad jeg betalte for de Par, jeg tog med mig over, Summen for Transporten ei være langt fra 3000 Mark, en Urimelighed. Uden Udsigt til en ordentlig Livsstilling i Danmark kan jeg slet ikke bære et saadant Tab."16

Edvard hørte broderens nødråb, gjorde sin indflydelse gældende og trak i et par tråde rundt omkring; sommeren 1882 var der så afgørende nyt fra København. En forening af mænd og kvinder, der ønskede at være anonyme, tilbød Brandes 4000 kroner årligt i de følgende ti år, hvis han til gengæld indvilligede $i$ at holde en række offentlige forelæsninger på Københavns Universitet.

Absolut et kærkomment og gunstigt tilbud, som Brandes da også straks takkede ja til i sit svarbrev, dateret 12. juli 1882. Ganske vist udtrykte han i samme brev en vis bekymring: "Det var visselig ikke med let Sind, at jeg forlod Danmark for at bosætte mig i Udlandet; men det er heller ikke med noget let Hjerte, at jeg bestemmer mig til at vende tilbage; thi jeg maa til Trods for de ikke ringe Forandringer, der $\mathrm{i}$ de sidste fem Aar er skete i Danmark, frygte for i visse Maader at passe mindre godt til Kjøbenhavn nu end før." ${ }^{\prime 17}$ Men det var rent spil 


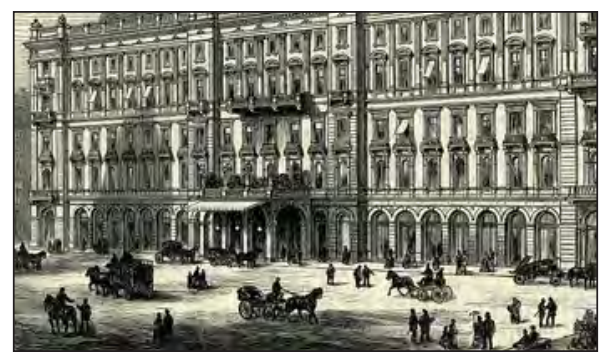

Holet Kaiserhof var Berlins forste luksushotel. Hér boldt Georg Brandes sin afskedsfest $i$ Berlin. Illustration fra 1876.

for galleriet. For faktum var, at Brandes nu kunne vende hjem uden at tabe ansigt og tilmed være økonomisk sikret de næste mange år.

Sagen var således afgjort: Familien Brandes ville forlade Berlin. Den 1. februar 1883 kunne det hele så ende, som det begyndte, med en fest. I Hotel Kaiserhofs store sal samledes over hundrede af byens spidser - forfattere, politikere, kunstnere, levemænd og borgerfruer - der alle ville bevidne den bortdragne dansker deres deltagelse inden afrejsen. Der blev hilst og skålet i glas på stilke, mens hyldesttaler og festdigte rungede i det store lokale.

Som ved afrejsen fra Køben-

\section{Noter}

1 Talen er optrykt i Georg Brandes: Samlede Skrifter, bd. 14, s. 559-564.

2 Georg Brandes: Levned, bd. 2, s. 246.

3 Ibid, s. 248.

4 Georg Brandes. Breve til Foraldrene 18721904, bd. 1, s. 125.

5 Ibid, s. 126.

6 Levned, bd. 2, s. 246.

7 Georg og Edvard Brandes. Brevveksling med Nordiske Forfattere og Videnskabs- havn i 1877, var der for så vidt stadig ikke noget at fejre. Succesen under det femårige ophold i Berlin matchede langtfra forventningerne, og Brandes blev aldrig det litterære og åndelige midtpunkt i Berlin, han havde håbet på. Alt for meget tid og energi var blevet brugt på at finde fast grund under fødderne og tilkæmpe sig en plads i de nye omgivelser. Og selv om han arbejdede meget og absolut havde sine lykkestunder, hvor han følte, han befandt sig i smørhullet af europæisk åndsliv, så savnede han i den grad sin position som bannerfører og strateg for den kulturkamp, der udspillede sig i Norden. Som Brandes meget præcist udtrykte det i sin afskedstale på Hotel Kaiserhof: 'I Tyskland kunde jeg ikke havet andet Maal end det uværdige at gøre mit Navn stedse mere bekendt. Men i Norden ligger alle mine Opgaver. I Norden er der en Ungdom, hvis Lærer jeg skal være (...)." 18

Den 6. februar 1883 satte

Brandes punktum i sin landflygtighed og forlod Berlin. En ny begyndelse ventede i København. Høvdingen var tilbage.

mand, bd. 2, s.4-5.

8 Breve til Forcldrene 1872-1904, bd. 1, s. 138.

9 Brevveksling med Nordiske Forfattere og Videnskabsmand, bd. 3, s. 289.

10 Levned, bd. 2, s. 322.

11 Breve til Foraldrene 1872-1904, bd. 1, s. 146.

12 Levned, bd. 2, s. 327-328.

13 Breve til Foraldrene 1872-1904, bd. 1, s. 208. 
14 Ibid, s. 226.

15 Brevveksling med Nordiske Forfattere og Videnskabsmand, bd. 2, s. 106.

16 Ibid, s. 114.
17 Brevet er gengivet i Levned, bd. 3, s. 3132.

18 Talen er gengivet i Levned, bd. 3, s. 5054. 